\title{
Biocompatibility of magnesium-zinc alloy in biodegradable orthopedic implants
}

\author{
DAOYUN CHEN $^{1}$, YAOHUA HE ${ }^{1}$, HAIRONG TAO $^{1}$, YAN ZHANG $^{1}$, YAO JIANG $^{1}$, \\ XIAONONG ZHANG $^{2}$ and SHAOXIANG ZHANG ${ }^{2}$ \\ ${ }^{1}$ Department of Orthopaedic Surgery, Shanghai Sixth People's Hospital; ${ }^{2}$ State Key Laboratory \\ of Metal Matrix Composites, School of Materials Science and Engineering, \\ Shanghai Jiaotong University, Shanghai, P.R. China
}

Received March 1, 2011; Accepted April 21, 2011

DOI: $10.3892 /$ ijmm.2011.707

\begin{abstract}
In this study, magnesium-zinc (Mg-Zn) alloy was investigated as a biodegradable orthopedic implant. MC3T3-E1 cell attachment, mineralization and osteogenic-specific mRNA expression were assessed for as measurements of the in vitro biocompatibility of $\mathrm{Mg}-\mathrm{Zn}$ alloy. In vivo degradation of the $\mathrm{Mg}-\mathrm{Zn}$ alloy and the accompanying new bone formation in the femoral marrow cavity were analyzed by scanning electron microscopy and histomorphological analysis. Results showed that MC3T3-E1 cells cultured on $\mathrm{Mg}-\mathrm{Zn}$ alloy samples manifested better attachment and mineralization ability, as well as improved mRNA expression of collagen $1 \alpha 1$ (COL1 $\alpha 1)$ and osteocalcin (OC), compared with cells seeded on poly-Llactic acid (PLLA) samples. In vivo experiments demonstrated that, compared with PLLA materials, the $\mathrm{Mg}-\mathrm{Zn}$ alloy not only degraded faster, but was accompanied by considerable new bone formation around the samples. Our data indicate that $\mathrm{Mg}-\mathrm{Zn}$ alloy has excellent biocompatibility for application as degradable bone implants.
\end{abstract}

\section{Introduction}

Magnesium (Mg) alloys have mechanical properties close to those of the natural bone and may corrode at $\mathrm{pH}$ levels of 7.4-7.6 as well as in the high chloride environment of the physiological systems (1-3). These intriguing characteristics have attracted much attention with respect to biodegradable bone-implant applications. However, the major obstacles in the clinical use of $\mathrm{Mg}$-based materials are its rapid degradation rate $(2,4)$. Therefore, in order to make the use of Mg-based materials feasible for orthopedic implantation, their corrosion resistance must be improved.

Correspondence to: Professor Yaohua He, Department of Orthopaedic Surgery, Shanghai Sixth People's Hospital, Shanghai Jiaotong University, 600 Yishan Road, Shanghai 200233, P.R. China

E-mail: heyaohua@sjtu.edu.cn

Key words: biocompatibility, osteoblast, gene expression, bone remodeling, $\mathrm{Mg}-\mathrm{Zn}$ alloy
It is suggested that alloys, especially Mg alloys containing rare earth elements, may be suited for the control of the corrosion rate $(1,2)$. However, the potentially toxic effects of some rare earth elements on cells are noteworthy $(5,6)$. Extensive investigations have been conducted to screen suitable elements for biomedical $\mathrm{Mg}$ alloys. Ca has been selected to produce a binary $\mathrm{Mg}-\mathrm{Ca}$ alloy for bone implants because it is beneficial to bone growth. An investigation by Li et al indicated that a $\mathrm{Mg}-\mathrm{Ca}$ alloy with about $1 \% \mathrm{Ca}$ content had optimal mechanical and corrosion properties (7), whereas a further increase in $\mathrm{Ca}$ content led to deterioration in these properties (8). Mn and $\mathrm{Zn}$ were also chosen as alloying elements (e.g., $\mathrm{Mg}-\mathrm{Mn}-\mathrm{Zn}$ ) due to their good biocompatibility $(9,10)$. It has been shown that the corrosion resistance of a Mg-1.0 Mn-1.0 Zn alloy in simulated body fluid (SBF) is slightly better than that of WE43 alloy (11). However, the biocompatibility of these samples with host tissue has not been comprehensively investigated.

In a previous study, we investigated the $\mathrm{Mg}-\mathrm{Zn}$ alloy as a biomedically degradable $\mathrm{Mg}$, and found that this alloy was degraded more slowly than the high-purity $\mathrm{Mg}$ in SBF (12). Animal implant experiments have demonstrated that no disorders of the liver, heart, kidney, or blood composition have been caused by the degradation of $\mathrm{Mg}-\mathrm{Zn}$ alloys $(12,13)$. Results indicate that $\mathrm{Mg}-\mathrm{Zn}$ alloys are basically safe for biomedical applications. However, as an orthopedic biodegradable biomaterial, it should be tested for biocompatibility with osteoblasts and bone tissue. Therefore, it is necessary to mimic the in vivo bio-environment using osteoblasts to study cell responses on the metallic interfaces. In this study, we cultured mouse pre-osteoblastic MC3T3-E1 cells with Mg-Zn alloys. The in vitro biocompatibility of the $\mathrm{Mg}-\mathrm{Zn}$ alloy was investigated by assessing cell attachment, mineralization, and osteogenic-specific mRNA expression. For the assessment of bone responses to $\mathrm{Mg}$ - $\mathrm{Zn}$ alloys, the in vivo degradation and new bone formation were subsequently determined.

\section{Materials and methods}

Sample preparation. $\mathrm{Mg}-\mathrm{Zn}$ alloy and high purity $\mathrm{Mg}$ were produced and provided by Shanghai Aoruiji Medical Technology Co., Ltd. The chemical composition is shown in Table I. PolyL-lactic acid (PLLA) samples were provided by Shanghai 
Table I. Chemical composition of the Mg-Zn alloy and of high purity Mg.

Chemical composition (wt.\%)

\begin{tabular}{lcccccccc}
\cline { 2 - 8 } Materials & $\mathrm{Mg}$ & $\mathrm{Fe}$ & $\mathrm{Si}$ & $\mathrm{Ni}$ & $\mathrm{Cu}$ & $\mathrm{Al}$ & $\mathrm{Mn}$ & $\mathrm{Zn}$ \\
\hline $\mathrm{Mg}$ & $\geq 99.99$ & $\leq 0.0014$ & $\leq 0.0016$ & $\leq 0.0001$ & $\leq 0.0004$ & $\leq 0.0005$ & $\leq 0.0004$ & - \\
$\mathrm{Mg}-\mathrm{Zn}$ & Balance & 0.0038 & 0.0016 & 0.0005 & 0.0005 & 0.0085 & 0.0004 & 5.621 \\
\hline
\end{tabular}

Jingtong Medical Technology Co., Ltd. Disk samples with a diameter of $10 \mathrm{~mm}$ and a height of $2 \mathrm{~mm}$ were used for the in vitro test. Cylindrical rods with a diameter of $4.5 \mathrm{~mm}$ and a length of $10 \mathrm{~mm}$ were used in the animal implant experiments. All samples were ultrasonically cleaned in distilled water, followed by sterilization with $29 \mathrm{kGy}$ of ${ }^{60} \mathrm{Co}$ radiation.

Cell culture. Mouse preosteoblast cell line MC3T3-E1 subclone cells (Chinese Academy of Sciences, Shanghai, China) were used for this study. The cells were cultured in T25 plastic bottles with Dulbecco's modified Eagle's medium (DMEM, Gibco, Gaithersburg, MD, USA), containing $10 \%$ fetal bovine serum (FBS, Gibco), 100 IU/ml penicillin (Sigma-Aldrich, St. Louis, MO, USA), and $100 \mathrm{mg} / \mathrm{ml}$ streptomycin (Sigma). The cells were incubated at $37^{\circ} \mathrm{C}$ in a humidified atmosphere of $5 \% \mathrm{CO}_{2}$ and $95 \%$ air. The growth medium was changed every 3 days. Cultured cells were detached by $0.25 \%$ trypsin/EDTA (Gibco), suspended in fresh culture medium, and used for the designed experiments.

Cell attachment assay. Attachment of MC3T3-E1 cells on the $\mathrm{Mg}-\mathrm{Zn}$ alloy were evaluated by cell counts and by scanning electron microscopy (SEM). PLLA was taken as the control material. The samples (diameter, $10 \mathrm{~mm}$; height, $2 \mathrm{~mm}$ ) were placed into a 24-well plate and seeded with a density of $1 \times 10^{5}$ cells $/ \mathrm{cm}^{2}$. Then DMEM supplemented with $10 \%$ FBS, $0.05 \mathrm{mM}$ L-ascorbic acid 2-phosphate (Sigma), and $10 \mathrm{mM}$ $\beta$-glycerophosphate (Sigma) was added to each well. For the cell count assessment, after each time point (1,2 and $4 \mathrm{~h})$, the samples were washed with phosphate buffer solution (PBS) to remove the unattached cells. These were fixed in $95 \%$ ethanol, followed by incubation with $0.01 \%$ acridine orange for $10 \mathrm{~min}$. The cells were observed using a fluorescence microscope (Nikon Eclipse 80i, Tokyo, Japan) with a 495-nm incident filter. Using the image analysis software, Image-Pro Plus (Media Cybernetics, Bethesda, MD, USA), five visual fields were included in each sample, and the results were expressed as the number of cells at x100 magnification. For the SEM assay, at the 2-h time point, the samples were washed with PBS, fixed in $2.5 \%$ glutaraldehyde, dehydrated with graded ethanol $(50,70$, $80,90,95,99$ and 100\%), and finally critical-point dried and gold-sputter-coated. Then they were examined using the SEM.

Osteogenic mineralization. MC3T3-E1 cells were seeded on the $\mathrm{Mg}-\mathrm{Zn}$ alloy or PLLA at a density of $1 \times 10^{5}$ cells/well in 24-well plates. The cells were cultured in DMEM supplemented with $10 \%$ FBS, $0.05 \mathrm{mM}$ L-ascorbic acid 2-phosphate, and $10 \mathrm{mM} \beta$-glycerophosphate. The medium was changed every 3 days. After 21 days, the medium was replaced by ambramycin
(50 $\mu \mathrm{g} / \mathrm{ml}$ solution) and incubated for $30 \mathrm{~min}$, followed by washing with PBS, and the cells were fixed in $95 \%$ ethanol. The mineralized nodule was observed by using a fluorescent microscope with a 495-nm incident filter. The area of the nodule was calculated by using the image analysis software, Image-Pro Plus, and expressed as the mineralized nodule area on the surface of a single material.

Qualitative real-time PCR. Cell seeding on the $\mathrm{Mg}-\mathrm{Zn}$ alloy and PLLA was performed as an assessment of osteogenic mineralization ability. Total-RNA was extracted using the TRIzol reagent (Invitrogen, Carlsbad, CA, USA) according to the manufacturer's instructions. Complementary DNA was synthesized using a PrimeScript first Strand cDNA Synthesis kit (Takara Biotechnology, Dalian, China). Reactions were performed in a PTC-200 Thermal Cycler PCR machine (BioRad, Waltham, MA, USA). Real-time PCR was performed using a quantitative real-time amplification system (LightCycler 480, Roche, Switzerland). SYBR-Green Premix Ex Taq II (Takara) was used in each reaction. Reactions were performed at 40 cycles $\left(95^{\circ} \mathrm{C}\right.$ for $5 \mathrm{sec}, 55^{\circ} \mathrm{C}$ for $30 \mathrm{sec}$, and $72^{\circ} \mathrm{C}$ for $30 \mathrm{sec})$. Primers used for real-time PCR were as follows: collagen $1 \alpha 1$ (COL1 $\alpha 1), 5$ '-GCTCCTCTTAGGGGCCACT-3' and 5'-CCACGTCTCACCATTGGGG-3'; alkaline phosphatase (ALP), 5'-CCAACTCTTTTGTGCCAGAGA-3', and 5'-GGC TACATTGGTGTTGAGCTTT-3'; osteocalcin (OC), 5'-GCA ATAAGGTAGTGAACAGACTCC-3' and 5'-GTTTGTAGG CGGTCTTCAAGC-3'; and GAPDH, 5'-GAGTCAACGG ATTTGGTCGT-3' and 5'-GACAAGCTTCCCGTTCTCAG-3'. Results were normalized against the GAPDH housekeeping gene, and relative gene expression was analyzed using the $2^{-\Delta \Delta \mathrm{Ct}}$ method. Each measurement was assessed in triplicate.

In vivo degradation and histological evaluation. Animal experiments were approved by the Ethics Committee of Shanghai Jiaotong University. A total of 24 adult New Zealand rabbits with a body weight of $2.0-2.5 \mathrm{~kg}$ were used in this study. The rabbits were randomly divided into two groups. In both the experimental and control groups, same-size rods (Mg-Zn alloy rod for the experimental group and PLLA rod for control group) were implanted in the femoral marrow cavity of each rabbit. Before surgery, a dose of $30 \mathrm{mg} / \mathrm{kg}$ sodium pentobarbital was administered by i.v. injection. Postoperatively, all rabbits received a subcutaneous injection of penicillin as a prophylactic antibiotic.

After 12 weeks of implantation, the bone samples with implants were fixed in $2.5 \%$ glutaraldehyde solution followed by embedding in methyl methacrylate. The embedded samples were then cut into $100-\mu \mathrm{m}$ sections, then microground to 

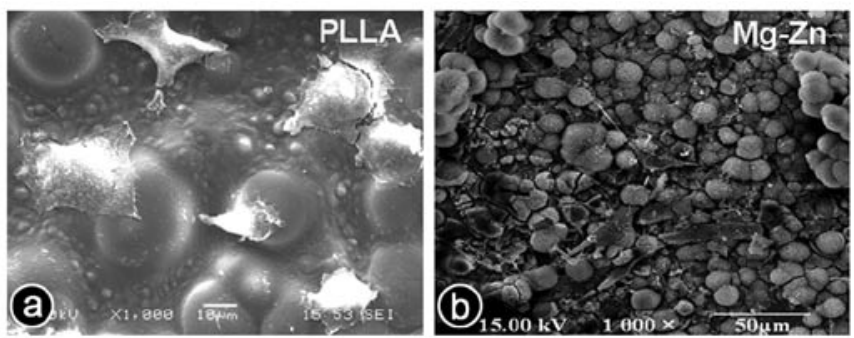

Figure 1. Cell morphology at a high magnification after 2 days incubation on the (b) Mg-Zn alloy and (a) PLLA samples.

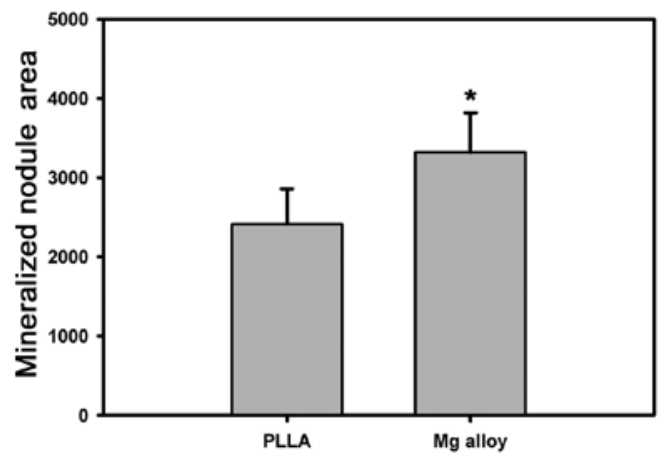

Figure 2. The area of mineralized nodules on the surface of the $\mathrm{Mg}-\mathrm{Zn}$ alloy and the PLLA samples ( $\left.{ }^{*} \mathrm{P}<0.05\right)$.

Table II. Comparison of the number of attached cells on Mg-Zn alloy and PLLA.

\begin{tabular}{lccc}
\hline Group & $1 \mathrm{~h}$ & $2 \mathrm{~h}$ & $4 \mathrm{~h}$ \\
\hline PLLA & $93.24 \pm 4.52$ & $131.28 \pm 8.02$ & $177.40 \pm 5.24$ \\
Mg-Zn alloy & $104.68 \pm 6.49^{\mathrm{a}}$ & $208.04 \pm 10.48^{\mathrm{a}}$ & $256.04 \pm 4.03^{\mathrm{a}}$
\end{tabular}

${ }^{\text {aP-value }}<0.05$.

50-70 $\mu \mathrm{m}$ thickness. For the in vivo degradation assay, the cross-section microstructure was observed under an optical microscope and an SEM. For histological evaluation, the crosssection of the implant and surrounding bone tissue were stained with van Gieson and observed using an optical microscope.

\section{Results}

Cell attachment assay. MC3T3-E1 cell attachment capacity on $\mathrm{Mg}-\mathrm{Zn}$ alloys was determined by acridine orange staining and SEM analysis. Differences in the cellular responses to the different surfaces were obvious. Table II shows that more MC3T3-E1 cells attached to the surface of the $\mathrm{Mg}-\mathrm{Zn}$ alloy than to the PLLA at the 1-h, 2-h and 4-h time points $(\mathrm{P}<0.05)$. Similar findings were demonstrated by SEM assays. After $2 \mathrm{~h}$ in culture, in comparison with the PLLA, more cells had spread and attached to the surface of the Mg-Zn alloy (Fig. 1).

Osteogenic mineralization. The effects of Mg-Zn alloy on mineralized nodule formation of MC3T3-E1 cells were determined
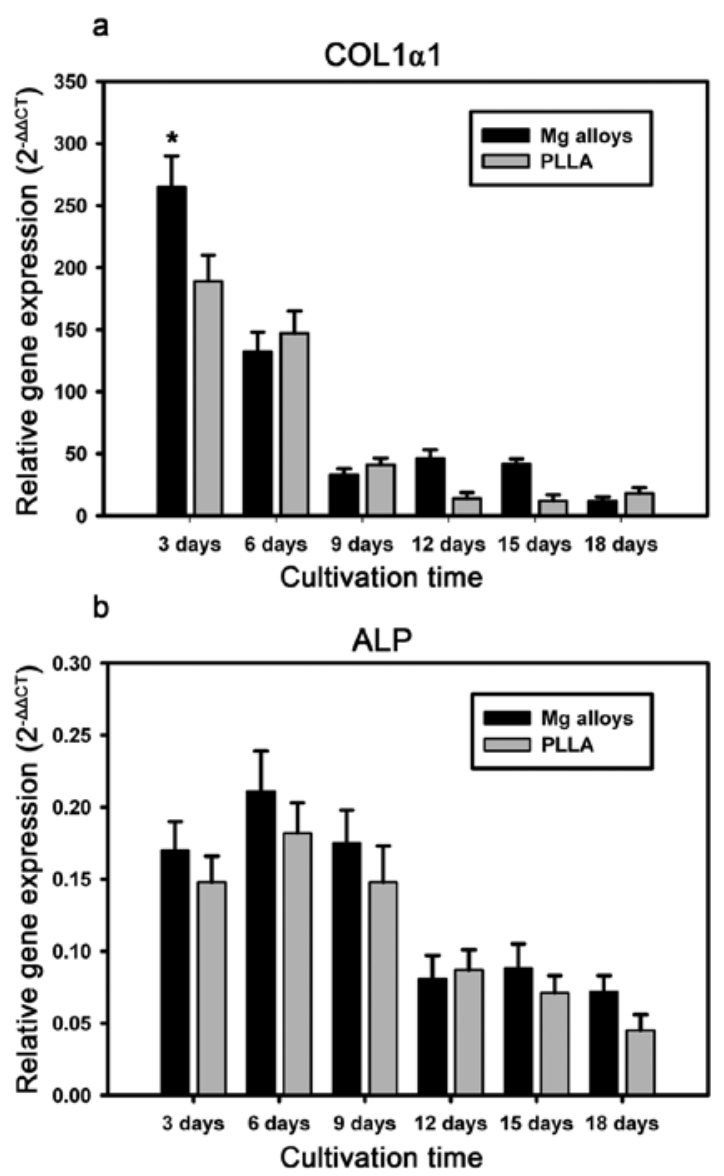

C

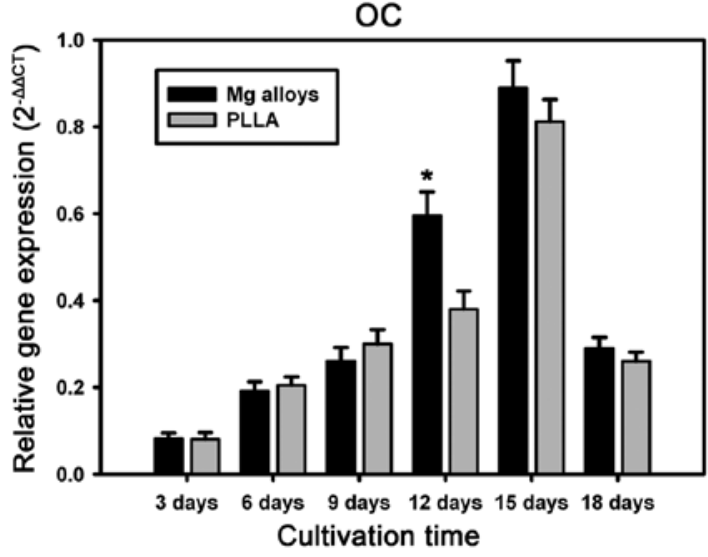

Figure 3. Osteogenic-specific mRNA expression level of (a) COL1 $\alpha 1$, (b) ALP and (c) OC between MC3T3-E1 cells seeded on Mg-Zn alloy and PLLA were determined by qualitative real-time PCR ( $\mathrm{P}<0.05)$.

by ambramycin staining. The area of mineralized nodules formed on the surface of the Mg-Zn alloy was greater $(\mathrm{P}<0.05)$ than that formed on the PLLA samples (Fig. 2).

Qualitative real-time PCR. Osteogenic-specific mRNA derived from MC3T3-E1 cells was assessed for the expression of COL1 1 1, ALP and OC transcripts. MC3T3-E1 cells seeded on both Mg-Zn alloy and PLLA samples expressed mRNA of COL1 $\alpha 1$, ALP and OC (Fig. 3). On Day 3, COL1 1 1 was highly expressed in both groups, then decreased with time. The expression level of COL1 $\alpha 1$ transcript in the $\mathrm{Mg}-\mathrm{Zn}$ alloy group was significantly higher than in the PLLA group after 

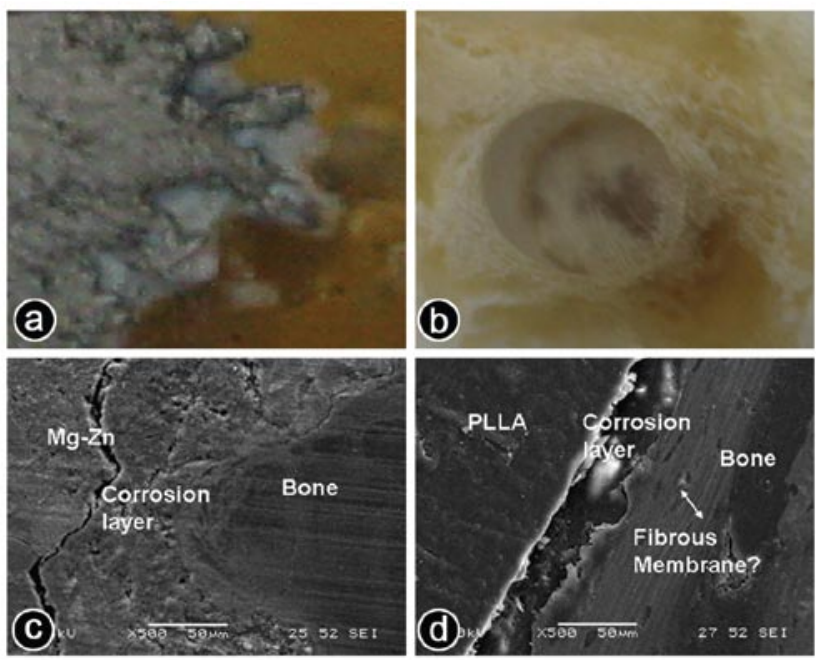

Figure 4. The SEM and optical images of the cross-section of bone and implants. ( $a$ and b) Optical images after the harvest samples were embedded in methyl methacrylate. (c and d) SEM observation of the cross-section images.
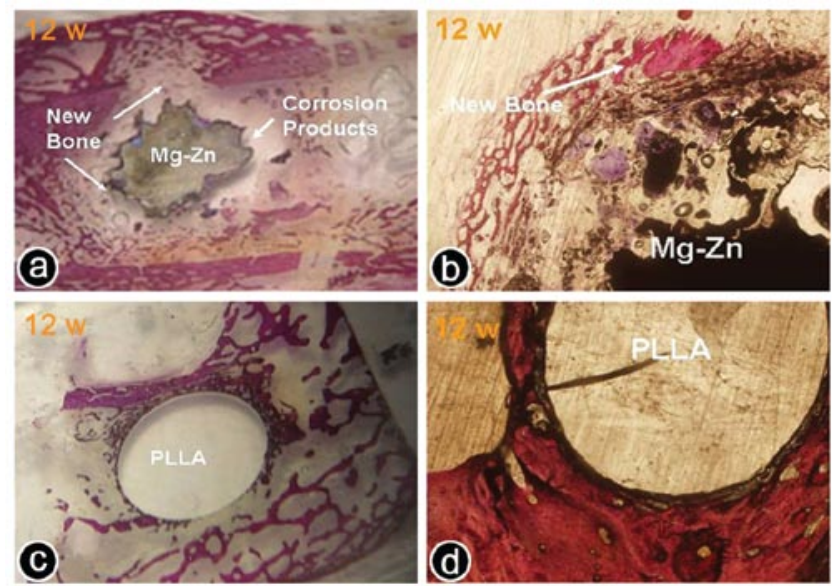

Figure 5. Images of methyl methacrylate embedded histological sections followed by van Gieson staining. ( $\mathrm{a}$ and b) $\mathrm{Mg}-\mathrm{Zn}$ alloy-bone samples, $\mathrm{x} 40$ (a) and x100 (b) magnification. (c and d) PLLA-bone samples, x40 (c) and x100 (d) magnification.

3 days. ALP mRNA expression reached a peak value at Day 6, followed by a steady decrease in the remaining culture periods. ALP transcript expression did not show a statistical difference between the two sample groups. OC mRNA transcript revealed a lower level at an early culture stage and reached a typical peak on Day 15, followed by a slight decrease. On Day 12, OC mRNA was expressed at a significantly higher level in the $\mathrm{Mg}-\mathrm{Zn}$ alloy group than in the PLLA group.

In vivo degradation and histological evaluation. Cross-sectional SEM and optical images of the bone and implants are shown in Fig. 4. After 12 weeks implantation, all $\mathrm{Mg}-\mathrm{Zn}$ alloy implants were tightly fixed. Meanwhile, the shape of the $\mathrm{Mg}-\mathrm{Zn}$ implant changed from a rod to an irregular shape, indicating that the implant had been corroded or degraded by body fluids. Compared with the Mg-Zn implant, PLLA degraded slowly in vivo (Fig. $4 \mathrm{a}$ and b). A filmy, fibrous membrane was seen at the interface between the PLLA implant and the bone tissue
(Fig. 4d). However, the fibrous membrane was not present at the alloy-bone interface (Fig. 4c).

Biodegradation of implants and new bone formation were also determined by van Gieson staining. Fig. 5 shows the optical microstructure of the implant-bone interfaces 12 weeks after implantation. It can be seen (Fig. 5a and b) that the $\mathrm{Mg}-\mathrm{Zn}$ alloy implants have markedly degraded; a degraded layer is clearly seen around the $\mathrm{Mg}-\mathrm{Zn}$ alloy implants. No inflammation or fibrous membrane formation is seen at the bone-alloy interface. In addition, abundant, newly formed bone can be observed surrounding the degradation layer. The bone trabeculae are connected and regularly aligned. However, the PLLA implants degraded slowly when compared with the $\mathrm{Mg}-\mathrm{Zn}$ alloy implants. As indicated in Fig. 5c and d, a continuous fibrous membrane was formed between the PLLA implants and bone tissue. In comparison with the $\mathrm{Mg}-\mathrm{Zn}$ alloy, a relatively small amount of new bone was formed around the PLLA implants.

\section{Discussion}

$\mathrm{Mg}$ alloy has been regarded as a promising candidate for bone implants because of its biodegradability and special mechanical properties (3). $\mathrm{Mg}^{2+}$ is one of the most important bivalent ions associated with the formation of biological apatite, it can directly influence bone resorption, and it can be an important factor in bone metabolism $(14,15)$. Further, the elastic module of $\mathrm{Mg}$ alloys is close to that of human bone. Therefore, it can minimize the 'stress shielding' phenomenon (3), which is usually caused by current stainless steel or titanium alloy implants. However, for orthopedic implants, two basic issues should be resolved before the clinical application of $\mathrm{Mg}$ alloys. One is its rapid degradation rate and consequent release of hydrogen gas, which may lead to the loss of internal fixation and result in adverse effects on the surrounding tissue. It is believed that corrosion resistance can be improved through surface modification and alloying methods $(3,9,16-18)$. The other critical issue is that implants should be totally biocompatible with bone tissue and be beneficial to osteoblastic growth and differentiation.

In our previous study, the in vitro degradation rate of $\mathrm{Mg}-\mathrm{Zn}$ alloy was confirmed to be much lower than that of high-purity $\mathrm{Mg}$ in SBF (12). In this study, we focus on its biocompatibility with osteoblasts for orthopedic applications. At the same time, we also determined implant-bone integration and new bone formation.

The effects of $\mathrm{Mg}-\mathrm{Zn}$ alloys on preosteoblast cell responses were assessed by measuring cell attachment, and osteogenic differentiation. According to the above experiments, the attachment and differentiation of MC3T3-E1 cells seeded on $\mathrm{Mg}-\mathrm{Zn}$ alloy substrates was more efficient compared to that of cells cultured on PLLA samples. $\mathrm{Mg}$ is known to be active in cell-adhesion mechanisms $(19,20)$, and to be necessary for calcium incorporation (21). Research has shown that modifying biomaterials with $\mathrm{Mg}^{2+}$ results in an increase in osteoblast adhesion (22), and Mg-substituted tricalcium phosphate has been confirmed to stimulate cell proliferation and the synthesis and secretion of collagenase (23). $\mathrm{Zn}^{2+}$ also plays a vital role in controlling the function of osteoblasts, increasing osteoblastic adhesion and upgrading the level of ALP (24). In addition, $\mathrm{Zn}$ and $\mathrm{Mg}$ ions in the coating may promote osteogenesis due 
to their stimulatory effects on osteoblastic cell proliferation and bone formation. A recent study has also indicated that cell adhesion is associated with their surface ability to adsorb extracellular matrix (ECM) proteins (25). The enhanced ability to adsorb proteins, such as vitronectin and fibronectin, results in better cell attachment to biomaterials. Osteoblastic cells express fibronectin in contact with biomaterials, which mediate cell attachment and proliferation $(26,27)$. In addition, proteins such as ECM proteins, cytoskeletal proteins, and membrane receptors are generally involved in cell-substrate interactions. Interactions between these proteins and their specific receptors induce signal transduction, which consequently influences cell adhesion, growth, and differentiation (28). Furthermore, different biomaterial surface properties are reflected in the $\mathrm{ECM}$, in particular, the molecular architecture of the ECM, including protein conformation $(29,30)$. This directly influences the ability of the cells to form adhesion complexes and ultimately affects many aspects of cell behavior.

To further investigate the effect of $\mathrm{Mg}-\mathrm{Zn}$ alloy on the osteogenic differentiation of preosteoblasts, we evaluated the osteogenic-specific mRNA expression of COL1 $\alpha 1$, ALP and OC. ALP is an early marker for osteogenic differentiation; the expression level of ALP is a key factor in determining osteoblast differentiation (31). COL1 11 is an essential component in bone formation, it contributes to matrix production, and it is associated with early-stage osteogenic differentiation (32). OC is the most abundant non-collagenous protein in bone, and it is a bone-specific marker for terminal osteoblast differentiation. In the present study, we have shown that MC3T3-E1 cells seeded on both Mg-Zn alloy and PLLA samples expressed COL1 $\alpha 1$, ALP and OC mRNA. It is worth noting that MC3T3-E1 cells seeded on $\mathrm{Mg}-\mathrm{Zn}$ alloy samples showed a significantly higher mRNA expression of COL1 $\alpha 1$ and OC than cells cultured on PLLA samples at different time points. It is likely that the reason for this observation is that interactions between the $\mathrm{Mg}-\mathrm{Zn}$ alloy and MC3T3-E1 cells promote the synthesis of ECM and thereby benefit from osteogenic differentiation of MC3T3-E1 cells. It also appears that $\mathrm{Mg}-\mathrm{Zn}$ alloy can serve as a suitable substrate for cultivation of osteoblasts.

The in vivo responses of $\mathrm{Mg}-\mathrm{Zn}$ alloy and the new bone formation were assessed by SEM and histological evaluation. After 12 weeks of implantation, newly formed bone was found around the implants of both Mg-Zn alloy and PLLA samples. No inflammation occurred at the interfaces of the bone or the implants. We can conclude that, similar to PLLA, Mg-Zn alloy has good biocompatibility with bone tissue. When we compared the amounts of new bone formation, we found that there were larger amounts of newly formed bone around the $\mathrm{Mg}-\mathrm{Zn}$ alloy implants than were around the PLLA samples. This might be explained by the release of low levels of $\mathrm{Mg}$ and $\mathrm{Zn}$ ions, which have been reported to enhance osteoblastic activity and promote new bone formation $(22,33,34)$. Optical images and SEM microstructure images clearly showed that a degradation layer had formed on the surface of the $\mathrm{Mg}-\mathrm{Zn}$ alloy implants. New bone tissue was in contact with the $\mathrm{Mg}-\mathrm{Zn}$ alloy through this degradation layer. In contrast, there was a lager gap and a continuous fibrous membrane at the interface of the bone and the PLLA implants. In the current study, although large amounts of new bone formed around the $\mathrm{Mg}-\mathrm{Zn}$ alloy, there were small gaps at the interface of the bone and residual $\mathrm{Mg}-\mathrm{Zn}$ alloy. It seems that the degradation rate of $\mathrm{Mg}-\mathrm{Zn}$ alloy in the femoral marrow cavity is faster than the rate of new bone formation. Therefore, further studies are needed to control the degradation rate of $\mathrm{Mg}-\mathrm{Zn}$ alloy so as to match the rate of new bone formation.

In conclusion, in the present study, $\mathrm{Mg}-\mathrm{Zn}$ alloy was investigated as a biodegradable orthopedic implant material, including its biological compatibility with preosteoblasts, and bone. MC3T3-E1 cells cultured on $\mathrm{Mg}-\mathrm{Zn}$ alloy samples showed better attachment, and mineralization ability, as well as improved mRNA expression of COL $1 \alpha 1$ and OC, compared with cells seeded on PLLA samples. Animal implant experiments indicated that $\mathrm{Mg}-\mathrm{Zn}$ alloy degraded faster than PLLA samples. At the same time, considerable new bone was formed around the $\mathrm{Mg}-\mathrm{Zn}$ alloy samples. In a word, $\mathrm{Mg}-\mathrm{Zn}$ alloys have excellent biocompatibility as degradable metallic materials for orthopedic application.

\section{Acknowledgements}

The present study was supported by the Natural Science Foundation of China (Nos. 30772182 and 81071452) and by a Shanghai Jiaotong University Interdisciplinary Research grant (No. YG2007MS26).

\section{References}

1. Witte F, Fischer J, Nellesen J, Crostack HA, Kaese V, Pisch A, Beckmann $F$ and Windhagen $H$ : In vitro and in vivo corrosion measurements of magnesium alloys. Biomaterials 27: 1013-1018, 2006.

2. Witte F, Kaese V, Haferkamp H, Switzer E, Meyer-Lindenberg A Wirth CJ and Windhagen $\mathrm{H}$ : In vivo corrosion of four magnesium alloys and the associated bone response. Biomaterials 26: 3557-3563, 2005.

3. Xu L, Yu G, Zhang E, Pan F and Yang K: In vivo corrosion behavior of Mg-Mn-Zn alloy for bone implant application. J Biomed Mater Res A 83: 703-711, 2007.

4. Wong HM, Yeung KW, Lam KO, Tam V, Chu PK, Luk KD and Cheung KM: A biodegradable polymer-based coating to control the performance of magnesium alloy orthopaedic implants. Biomaterials 31: 2084-2096, 2010.

5. Ku CH, Pioletti DP, Browne M and Gregson PJ: Effect of different Ti-6Al-4V surface treatments on osteoblasts behaviour. Biomaterials 23: 1447-1454, 2002.

6. Nakamura Y, Tsumura Y, Tonogai Y, Shibata T and Ito Y: Differences in behavior among the chlorides of seven rare earth elements administered intravenously to rats. Fundam Appl Toxicol 37: 106-116, 1997.

7. Li Z, Gu X, Lou S and Zheng Y: The development of binary $\mathrm{Mg}-\mathrm{Ca}$ alloys for use as biodegradable materials within bone. Biomaterials 29: 1329-1344, 2008.

8. Vojtech D, Ciova H and Volenec K: Investigation of magnesium-based alloys for biomedical applications. Kovove Mater 44: 211-213, 2006.

9. Yin D, Zhang E and Zeng S: Effect of Zn on mechanical property and corrosion property of extruded $\mathrm{Mg}-\mathrm{Zn}-\mathrm{Mn}$ alloy. Trans Nonferrous Metals Soc 18: 763-768, 2008.

10. Zhang E, Yang L, Xu J and Chen H: Microstructure, mechanical properties and bio-corrosion properties of $\mathrm{Mg}-\mathrm{Si}(-\mathrm{Ca}, \mathrm{Zn})$ alloy for biomedical application. Acta Biomater 6: 1756-1762, 2010.

11. Xu L, Zhang E, Yin D, Zeng S and Yang K: In vitro corrosion behaviour of $\mathrm{Mg}$ alloys in a phosphate buffered solution for bone implant application. J Mater Sci Mater Med 19: 1017-1025, 2008.

12. He YH, Tao HR, Zhang Y, Jiang Y, Zhang SX, Zhao CL, Li JN, Zhang BL, Song Y and Zhang XN: Biocompatibility of bio-Mg-Zn alloy within bone with heart, liver, kidney and spleen. Chin Sci Bull 54: 484-491, 2009.

13. Zhang S, Zhang X, Zhao C, Li J, Song Y, Xie C, Tao H, Zhang Y, He Y, Jiang Y and Bian Y: Research on an Mg-Zn alloy as a degradable biomaterial. Acta Biomater 6: 626-640, 2010. 
14. Kim SR, Lee JH, Kim YT, Riu DH, Jung SJ, Lee YJ, Chung SC and Kim YH: Synthesis of $\mathrm{Si}, \mathrm{Mg}$ substituted hydroxyapatites and their sintering behaviors. Biomaterials 24: 1389-1398, 2003.

15. Marie PJ, Travers R and Delvin EE: Influence of magnesium supplementation on bone turnover in the normal young mouse. Calcif Tissue Int 35: 755-761, 1983.

16. Gu XN, Zheng W, Cheng Y and Zheng YF: A study on alkaline heat treated Mg-Ca alloy for the control of the biocorrosion rate. Acta Biomater 5: 2790-2799, 2009.

17. Li GY, Lian JS, Niu LY, Jiang ZH and Jiang Q: Growth of zinc phosphate coatings on AZ91D magnesium alloy. Surf Coat Technol 201: 1814-1820, 2006.

18. Wang YQ, Wu K and Zheng MY: Effects of reinforcement phases in magnesium matrix composites on microarc discharge behavio and characteristics of microarc oxidation coatings. Surf Coat Technol 201: 353-360, 2006.

19. Hynes RO: Integrins: versatility, modulation, and signaling in cell adhesion. Cell 69: 11-25, 1992.

20. Paul W and Sharma CP: Nanoceramic matrices: biomedical applications. Am J Biochem Biotechnol 2: 41-48, 2006.

21. Serre CM, Papillard M, Chavassieux P, Voegel JC and Boivin G: Influence of magnesium substitution on a collagen-apatite biomaterial on the production of a calcifying matrix by human osteoblasts. J Biomed Mater Res 42: 626-633, 1998.

22. Zreiqat H, Howlett CR, Zannettino A, Evans P, Schulze-Tanzil G Knabe $C$ and Shakibaei M: Mechanisms of magnesium-stimulated adhesion of osteoblastic cells to commonly used orthopaedic implants. J Biomed Mater Res 62: 175-184, 2002.

23. LeGeros RZ, Gatti AM, Kijkowska R and Mijares DQ: $\mathrm{Mg}$-substituted tricalcium phosphates: formation and properties. Key Eng Mater 254-256: 127-130, 2004.

24. Yamaguchi M, Oishi H and Suketa Y: Stimulatory effect of zinc on bone formation in tissue culture. Biochem Pharmacol 36 4007-4012, 1987.
25. Faucheux N, Schweiss R, Lutzow K, Werner C and Groth T: Self-assembled monolayers with different terminating groups as model substrates for cell adhesion studies. Biomaterials 25: 2721-2730, 2004

26. Lacouture ME, Schaffer JL and Klickstein LB: A comparison of type I collagen, fibronectin, and vitronectin in supporting adhesion of mechanically strained osteoblasts. J Bone Miner Res 17: 481-492, 2002.

27. Yang Y, Cavin R and Ong JL: Protein adsorption on titanium surfaces and their effect on osteoblast attachment. J Biomed Mater Res A 67: 344-349, 2003.

28. Anselme K: Osteoblast adhesion on biomaterials. Biomaterials 21: 667-681, 2000

29. Keselowsky BG, Collard DM and Garcia AJ: Surface chemistry modulates fibronectin conformation and directs integrin binding and specificity to control cell adhesion. J Biomed Mater Res A 66: 247-259, 2003.

30. Thull R: Physicochemical principles of tissue material interactions. Biomol Eng 19: 43-50, 2002.

31. Igarashi M, Kamiya N, Hasegawa M, Kasuya T, Takahashi $T$ and Takagi M: Inductive effects of dexamethasone on the gene expression of Cbfa1, Osterix and bone matrix proteins during differentiation of cultured primary rat osteoblasts. J Mol Histol 35: 3-10, 2004.

32. Ignatius A, Blessing H, Liedert A, Schmidt C, Neidlinger-Wilke C, Kaspar D, Friemert B and Claes L: Tissue engineering of bone: effects of mechanical strain on osteoblastic cells in type I collagen matrices. Biomaterials 26: 311-318, 2005.

33. Hashizume $M$ and Yamaguchi M: Stimulatory effect of betaalanyl-L-histidinato zinc on cell proliferation is dependent on protein synthesis in osteoblastic MC3T3-E1 cells. Mol Cell Biochem 122: 59-64, 1993.

34. Staiger MP, Pietak AM, Huadmai J and Dias G: Magnesium and its alloys as orthopedic biomaterials: a review. Biomaterials 27: 1728-1734, 2006. 